\title{
Air pollution and female fertility: a systematic review of literature
}

\author{
Alessandro Conforti ${ }^{1 *}$ D, Marika Mascia', Giuseppina Cioffi ${ }^{1}$, Cristina De Angelis ${ }^{2,3}$, Giuseppe Coppola ${ }^{2}$, \\ Pasquale De Rosa ${ }^{1}$, Rosario Pivonello ${ }^{3}$, Carlo Alviggi, ${ }^{1,4}$ and Giuseppe De Placido ${ }^{1}$
}

\begin{abstract}
Air pollution is a cause of concern for human health. For instance, it is associated with an increased risk for cancer, cardiovascular and respiratory disorders. In vitro and in vivo studies suggested that air pollutants could act as endocrine disruptors, promote oxidative stress and exert genotoxic effect. Whether air pollution affects female infertility is under debate. The aim of the present study was to conduct a systematic review of studies that evaluated the impact of air pollution on female infertility. We systematically searched the MEDLINE (PubMed) and SCOPUS databases to identify all relevant studies published before October 2017. No time or language restrictions were adopted, and queries were limited to human studies. We also hand-searched the reference lists of relevant studies to ensure we did not miss pertinent studies. The risk of bias and quality assessment of the studies identified were performed using the Newcastle-Ottawa Scale. Primary outcomes were conception rate after spontaneous intercourse and live birth rate after in vitro fertilization (IVF) procedures. Secondary outcomes were first trimester miscarriage, stillbirths, infertility, number of oocytes and embryo retrieved. Eleven articles were included in the analysis. We found that in the IVF population, nitrogen dioxide and ozone were associated with a reduced live birth rate while particulate matter of $10 \mathrm{~mm}$ was associated with increased miscarriage. Furthermore, in the general population, particulate matter of $2.5 \mathrm{~mm}$ and between 2.5 and $10 \mathrm{~mm}$ were associated with reduced fecundability, whereas sulfur dioxide, carbon monoxide and nitrogen dioxide might promote miscarriage and stillbirths. The main limitation of our findigns resides in the fact that the desegn of studies included are observational and retrospective. Furthermore, there was a wide heterogenity among studies. Although larger trials are required before drawing definitive conclusions, it seems that air pollution could represent a matter of concern for female infertility.
\end{abstract}

Keywords: Air pollution, IVF, Miscarriage, Live birth rate

\section{Introduction}

Female infertility has increased in recent years [1]. It was estimated that this condition affects 1 in seven couples in developed countries [2]. Most cases of female infertility are related to specific disorders, namely, ovulatory disorders, endometriosis, chromosomal abnormalities and male factors [3-7]. There is also evidence that air pollutant could play a role in the pathogenesis of female infertility [8-10]. Air pollution appears to be a cause of concern for human health. For instance, it has been associated with an increased risk of cancer [11], and cardiovascular [12] and

\footnotetext{
* Correspondence: confale@hotmail.it

'Dipartimento di Neuroscienze, Scienze Riproduttive ed

Odontostomatologiche, Sezione di Ginecologia ed Ostetricia, Centro di

Sterilità Università "Federico II" di Napoli, Naples, Italy

Full list of author information is available at the end of the article
}

respiratory disorders in adults and children [13, 14]. In addition, air pollutants have been associated with adverse perinatal outcomes $[15,16]$.

Anthropogenic activities, namely traffic, industrial facilities and combustion of fossil fuels, which are particularly intense in large cities and in proximity of farms, are the main sources of health-related air pollutants. Air pollutants are in four main categories: gaseous pollutants (sulfur dioxide $\left[\mathrm{SO}_{2}\right]$, nitrate oxide $\left[\mathrm{NO}_{2}\right]$ and carbon monoxide $[\mathrm{CO}]$ ), organic compounds (organic solvents or dioxins), heavy metals (lead and copper) and particulate matter $\left(\mathrm{PM}_{10} \mathrm{PM}_{2.5-10}\right.$ and $\left.\mathrm{PM}_{2.5}\right)$ [17]. Ingestion and inhalation are the most common routes of exposure [17]. Ingestion is also facilitated by the fact that air pollution contributes to the contamination of food and water [18]. Some air pollutants, namely $\mathrm{Cu}, \mathrm{Pb}$ and diesel exhaust seem to

(c) The Author(s). 2018 Open Access This article is distributed under the terms of the Creative Commons Attribution 4.0 International License (http://creativecommons.org/licenses/by/4.0/), which permits unrestricted use, distribution, and 
exert endocrine activity [19] that could affect female reproduction. Moreover, these endocrine "disruptors" exert estrogenic, antiestrogenic and antiandrogenic activity and some could interfere with the thyroid axis and influence metabolic disorders, such as insulin resistance and obesity, which are strictly related to infertility [20-22]. The increase in female infertility seems to parallel the increase in toxic emissions, which suggests that the impact of air pollution on human health could increase in the next years [23, 24]. In an attempt to summarize current evidence, we carried out a systematic review of studies devoted to the impact of air pollutions on female infertility.

\section{Material and methods \\ Protocol and eligibility criteria}

The present study was exempt from institutional and ethics board approval because it did not involve human intervention. We adhered to the Preferred Reporting Items for Systematic Reviews and Meta-Analyses (PRISMA) guidelines [25]. The selection criteria are described according to PICO (Patients, Intervention, Comparison, and Outcomes). In detail, we evaluated fertility outcomes in women on reproductive age (in the general and IVF populations) in relation to exposure to air pollutants (Additional file 1: Table S1).

\section{Search strategy}

We conducted a systematic search using MEDLINE (PubMed) and SCOPUS databases to identify all relevant studies published before October 2017. Combinations of the following keywords and MESH search terms were used: "air pollutants" AND ("miscarriage" OR "embryo" OR "pregnancy" OR "IVF OR "fecundability" OR "infertility" OR "menstrual disorders"). No time or language restrictions were adopted, and queries were limited to human studies. We also hand-searched reference lists of relevant studies to ensure we did not miss pertinent studies.

\section{Selection of studies}

Four reviewers (G.C., M.M., G.CO and P.D.) independently evaluated titles and abstracts. Duplications were removed using Endnote online software and manually. Disagreements were resolved by discussion with a third authors (A.C. and C.D.), and if required, with the involvement of the most experienced authors (R.P.,C.A., G.D.). Articles were included only if they appeared in peer-reviewed journals. Case series, case reports, book chapters, congress abstracts and grey literature [26], which includes a range of documents not controlled by commercial publishing organization, were not included.

\section{Data extraction}

Data were extracted independently by four reviewers (G.C., M.M., G.CO and P.D.) using predefined data fields, including study quality indicators. Discrepancies were resolved by discussion with the senior authors (R.P., C.A. and G.D.).

Risk of bias, summary measures and synthesis of the results The risk of bias and quality assessment of the included studies were performed adopting the Newcastle-Ottawa Scale (NOS) [27]. Four authors (A.C, C.D., G.C. and P.D.) independently assessed the risk bias for each study. The senior authors (R.P., C.A. and G.D.) resolved conflicts. The NOS score was used to evaluate the studies included, and judgment on each one was passed according to three issues: selection of the study group, comparability between groups, and ascertainment of exposed/not exposed cohorts. Primary outcomes were conception rate after spontaneous intercourse and live birth rate after IVF procedures. Secondary outcomes were first trimester miscarriage, stillbirths, infertility, number of oocytes retrieved and embryos transferred.

\section{Results \\ Study selection and characteristics}

A total of 4687 items were identified (Pubmed 2834 and Scopus 1853). A total of 2013 duplicates were removed manually and using the EndNote online library. The titles and abstracts of 2674 papers were scrutinized and 21 full papers were assessed for eligibility. Ten papers were excluded because they did not fulfill the inclusion criteria. Eleven articles were included in the analysis (Fig. 1). The characteristics of the studies included in the present study are reported in Table 1 .

\section{Risk of bias}

The risk of bias was evaluated with the NOS score and is reported in Table 1.

\section{Summary of results}

We summarized our findings considering per each pollutant both IVF women and reproductive age women in general population (Table 2).

$\mathrm{NO}_{2}$

\section{IVF cycles}

Increases in $\mathrm{NO}_{2}$ concentrations were significantly associated with a lower live birth rate especially from embryo transfer to pregnancy test (OR $0.76,95 \%$ CI $0.66-0.86$, per $0.01 \mathrm{ppm}$ increase) [28]. No effect on the number of oocytes retrieved or embryo transferred was observed [28].

\section{General population}

In a cross-sectional study involving women of reproductive age between 15 and 40 years, the fertility rate was not 


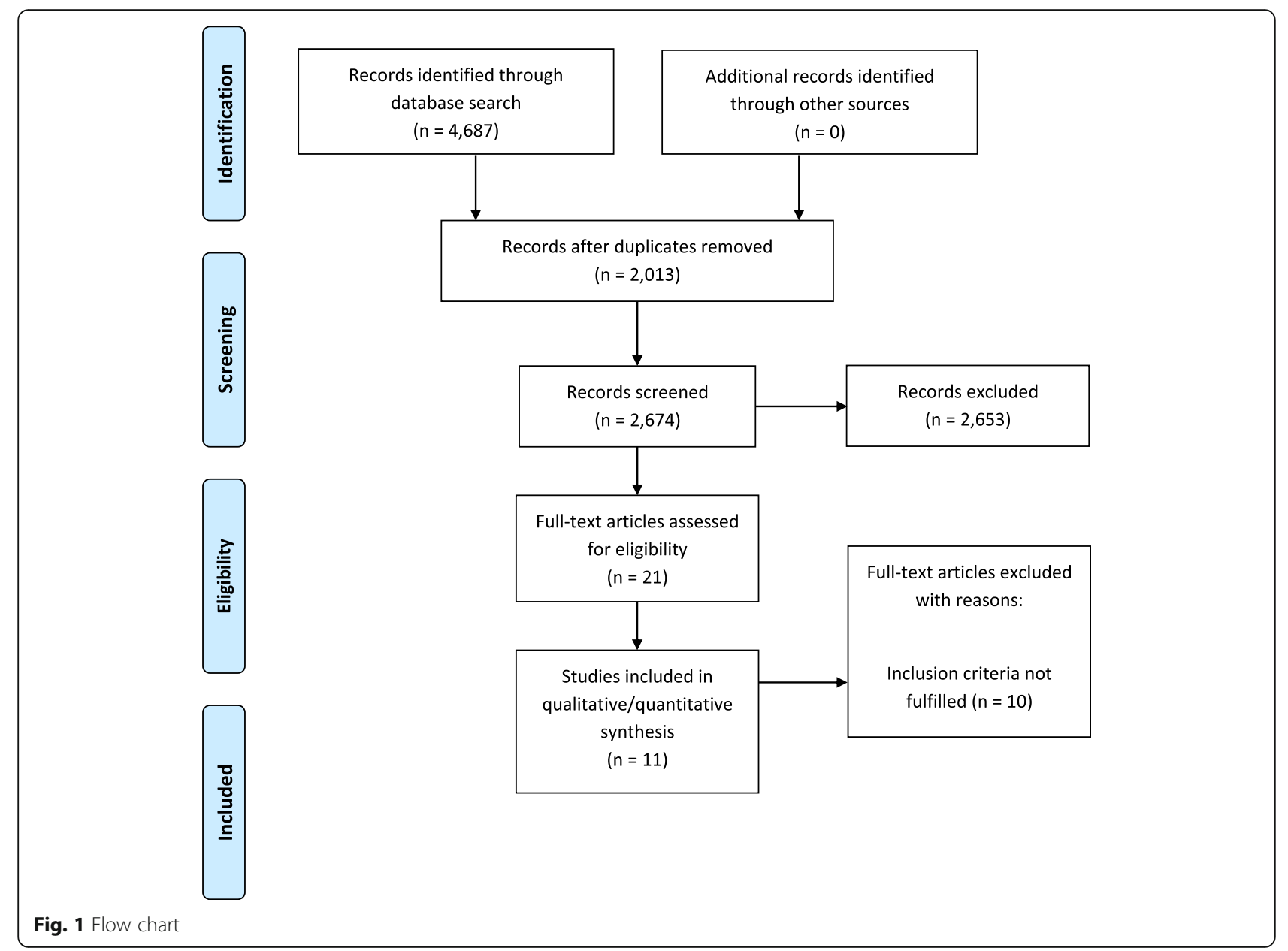

significantly associated with $\mathrm{NO}_{2}$ exposure (OR 0.97, 95\% CI 0.94-1.003) [9]. In contrast, another retrospective cohort study, showed that there was a significant decreased fecundability ratio per each increase of $10 \mu \mathrm{g} / \mathrm{m}^{3} \mathrm{NO}_{2}$ exposure (OR 0.72, 95\% CI 0.53-0.97) [29]. Miscarriage rate was significantly increased in women exposed to $\mathrm{NO}_{2}$ compared to not exposed group (OR 1.16, 95\% CI 1.01-1.28, per each 10-ppb increase in $\mathrm{NO}_{2}$ concentration) [30].

\section{CO}

\section{General population}

Exposure to $\mathrm{CO}$ was significantly associated with stillbirth in the second $(\mathrm{OR}=1.14,95 \% \mathrm{CI}: 1.01,1.28)$ and third trimester $(\mathrm{OR}=1.14,95 \% \mathrm{CI}: 1.06,1.24)$ [30]. No significant association with first trimester miscarriage was reported $(\mathrm{OR}=1.14,95 \%$ CI $0.98,1.32)$ [30].

\section{$\mathrm{O}_{3}$}

\section{IVF-cycles}

A detrimental effect was observed in terms of live birth rate in women exposed to $\mathrm{O}_{3}$ from embryo transfer to date of live birth (OR 0.62, 95\% CI 0.48-0.81, per $0.02 \mathrm{ppm}$ increase) [28]. No effect on the number of oocytes retrieved or embryo transferred was observed [28].

\section{General population}

Only one study assessed the fecundability rate in the general population but no difference was reported between exposed and unexposed group [29].

\section{$\mathrm{PM}_{2.5}$}

\section{IVF cycles}

Exposure to $\mathrm{PM}_{2.5}$ during embryo culture was associated with a decreased conception rate (OR 0.90, 95\% CI $0.82-0.99$, per $8 \mu \mathrm{g} / \mathrm{m}^{3}$ increase) but not with live birth rates [28]. No effect on the number of oocytes retrieved or embryo transferred was observed [28].

\section{General population}

Multivariate hazard ratio (HR) analysis did not reveal any association with infertility considering 2 years average exposure (HR 1.09, 95\% CI 0.77-1.55), 4 years average exposure (HR 0.91, 95\% CI 0.78-1.05) and cumulative average exposure (HR 1.05, 95\% CI 0.93-1.20) [8]. Consistently, in another trial multivariate analysis did not reveal 


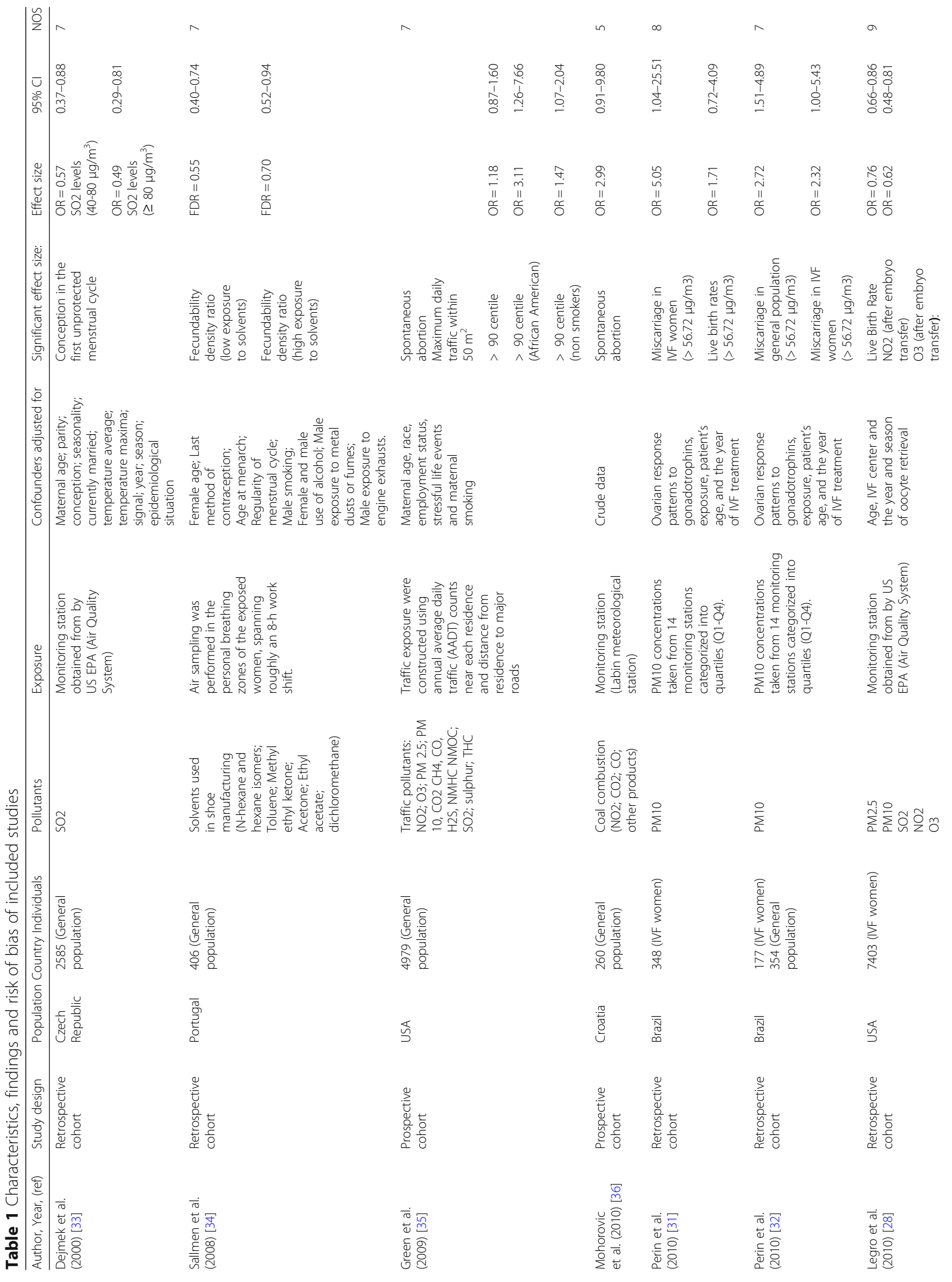




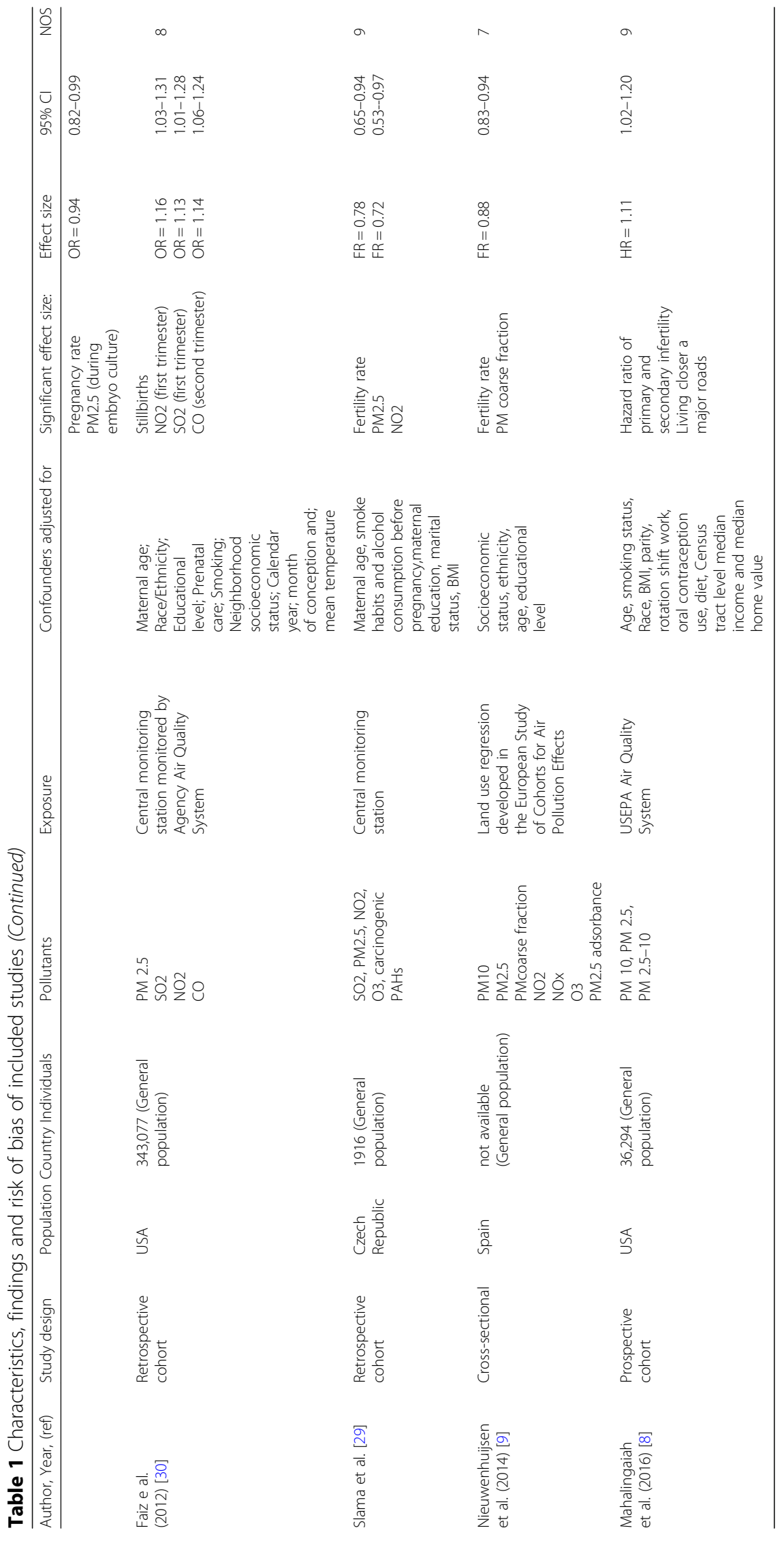


Table 2 Synthesis of results

\begin{tabular}{|c|c|c|}
\hline Type of Pollutant & Population & Effect \\
\hline \multirow[t]{2}{*}{$\mathrm{NO}_{2}$} & IVF & Lower live birth rates \\
\hline & General population & Higher miscarriage rate \\
\hline $\mathrm{CO}$ & General population & $\begin{array}{l}\text { Higher stillbirth in second } \\
\text { and third trimester }\end{array}$ \\
\hline $\mathrm{O}_{3}$ & IVF & Lower live birth rates \\
\hline \multirow[t]{2}{*}{$\mathrm{PM}_{2.5}$} & IVF & Lower pregnancy rates \\
\hline & General population & $\begin{array}{l}\text { Reduced fecundability } \\
\text { ratio }\end{array}$ \\
\hline \multirow[t]{2}{*}{$\mathrm{PM}_{10}$} & IVF & Higher miscarriage rate \\
\hline & General population & Higher miscarriage rate \\
\hline $\mathrm{PM}_{2.5-10}$ & General population & Reduced fertility rate \\
\hline \multirow[t]{2}{*}{$\mathrm{SO}_{2}$} & IVF & No effect \\
\hline & General population & $\begin{array}{l}\text { Higher early miscarriage } \\
\text { and third trimester } \\
\text { still births. Reduced } \\
\text { conception rate }\end{array}$ \\
\hline Traffic pollutants & General population & $\begin{array}{l}\text { Higher miscarriage rate; } \\
\text { Higher infertility rates. }\end{array}$ \\
\hline $\begin{array}{l}\text { Coal combustion } \\
\text { products }\end{array}$ & General population & Higher trend of miscarriage \\
\hline
\end{tabular}

any association with fertility rate [9]. On the other hand, The adjusted fecundability ratio was significantly decreased with each increase of 10 units $(0.78,95 \%$ CI $0.65-0.94)$ [29]. No statistically significant difference was observed in terms of late (second and third trimester) or early miscarriage (first trimester) [30].

$\mathrm{PM}_{2.5-10}$

\section{General population}

Multivariate HR analysis did not reveal any association between infertility and $\mathrm{PM}_{2.5-10}$ considering 2-year average exposure (HR 1.10, 95\% CI 0.98-1.23), 4 year average exposure (HR 1.05, 95\% CI 0.93-1.19) and cumulative exposure (HR 1.10, 95\% CI 0.99-1.22) [8]. Conversely, another study reported a significant reduction of spontaneous fertility rate in women exposed to $\mathrm{PM}_{2.5-10}$ (incidence risk ratio: $0.88,95 \%$ CI $0.84,0.94$ ) [9].

\section{$\mathrm{PM}_{10}$ \\ IVF cycles}

No significant effect was observed in terms of live birth rate, number of oocytes retrieved or embryos transferred in exposed women undergoing their first IVF cycle [28]. Furthermore, no significant effect was observed in the amount of gonadotropin used, number of oocytes retrieved, number of MII oocytes, embryo quality, clinical and live birth rate $[26,31]$. A higher risk of miscarriage was observed in women with a higher exposure to $\mathrm{PM}_{10}$ (> $56.72 \mu \mathrm{g} / \mathrm{m}^{3}$ ) comparing with those exposed to lower amount of $\mathrm{PM}_{10}\left(\leq 56.72 \mu \mathrm{g} / \mathrm{m}^{3}\right)(\mathrm{OR} 5.0595 \% \mathrm{CI}$ 1.04-25-51) [31].

\section{General population}

Multivariate adjusted HR analysis per year did not reveal any association with infertility considering 2 years average exposure (HR 1.04, 95\% CI 0.96-1.11), 4 years average exposure (HR 0.99, 95\% CI 0.91-1.08) and cumulative average exposure (HR 1.06, 95\% CI 0.99-1.13) infertility [8]. Multivariate incidence risk (IRR) ratio adjusted did not reveal any association between $\mathrm{PM}_{10}$ exposure and fertility rate (IRR 0.99, 95\% CI 0.96-1.02) [9]. A significant association with early miscarriage was observed in women exposed to over $56.72 \mu \mathrm{g} / \mathrm{m} 3$. [32].

\section{$\mathrm{SO}_{2}$}

\section{IVF cycles}

Exposure to $\mathrm{SO}_{2}$ did not significantly affect birth rate, number of oocytes retrieved or embryos transferred in women undergoing their first IVF cycle [28].

\section{General population}

No differences in terms of adjusted fecundability rate was observed per an increase of 10 units in the $\mathrm{SO}_{2}$ pollutant levels [29]. Conversely, in another study, the fecundability in the first unprotected menstrual cycle was significantly reduced only in couples exposed in the second month before conception to the following SO2 levels: $40-80 \mu \mathrm{g} / \mathrm{m}^{3}$ (OR 0.57, 95\% CI 0.37-0.88); $\geq 80 \mu \mathrm{g} / \mathrm{m}^{3}$ (OR 0.49, 95\% CI 0.29-0.81) [33]. The adjusted odds of miscarriage were significantly associated to $\mathrm{SO}_{2}$ exposure (OR $1.13,95 \% \mathrm{CI}$ 1.01-1.28 per each $3 \mathrm{ppb}$ increase in concentration) [30].

\section{Organic solvents \\ General population}

Female exposure to air contaminated with organic solvents (hexane and hexane isomers, toluene, methyl ethyl ketone, acetone, ethyl acetate, isopropyl alcohol and dichloromethane, $\mathrm{n}$-hexane, hexane isomers and toluene) was associated with reduced fecundability density ratio (FDR $=0.55$, 95\% CI 0.40-0.74) for low exposure (exposure index 0.01-0.14), and for high exposure (exposure index $>0.14$ ), (FDR $=0.70,95 \%$ CI 0.52.0.94). Moreover, exposure for less than 6 years was more strongly associated with reduced FDR in both low (FDR $=0.50,95 \% \mathrm{Cl}$ 0.30 to 0.83 ) and high exposure groups (FDR $=0.50,95 \%$ CI 0.28-0.90) [34].

\section{Traffic pollutants}

\section{General population}

In a large cohort study involving 4979 women, traffic pollutants were associated with an increased but not with significant risk of miscarriage rate among women exposed to a maximum annual average of traffic pollutants within 
$50 \mathrm{~m}$ (AOR 1.18 95\%, CI 0.87-1.60). A significant association was observed in a subgroup analysis involving African Americans (AOR $=3.11 ; 95 \% \mathrm{CI}, 1.26-7.66$ ) and nonsmokers (AOR $=1.47 ; 95 \% \mathrm{CI}, 1.07-2.04)$ [35]. In another large cohort study, women living closer to a major road had a higher risk of infertility than did women living far from a major road (HR, $1.1195 \%$ CI: 1.02-1.20) [8].

\section{Coal combustion pollutants General population}

In a small prospective study of 260 women, the miscarriage rate was higher, albeit not significantly, in women exposed to coal combustion pollutants than in non-exposed women (OR 2.99, 95\% CI 0.91-9.80) [36] .

\section{Discussion}

Only 11 studies have evaluated the potential effect of air pollutants on female reproduction.. In the IVF context, $\mathrm{NO}_{2}$ and $\mathrm{O}_{3}$ were associated with impaired live-birth rates. In addition, exposure to high levels of $\mathrm{PM}_{10}\left(>56.72 \mu \mathrm{g} / \mathrm{m}^{3}\right)$ resulted in an increased miscarriage rate after IVF procedures. Consistently, no study reported a significant effect on other quantitative (i.e. number of oocytes retrieved, number of embryos transferred, and consumption of gonadotropin) and qualitative (embryo quality, and number of MII oocytes) IVF outcomes $[28,31,32]$. In natural conception, reduced fecundability was associated with solvents and $\mathrm{SO}_{2}[33,34]$. Notably while abortion rate was associated with traffic pollutants [8,35], and in particular $\mathrm{SO}_{2}$ and $\mathrm{NO}_{2}$ [30], no clear relation to coal combustion pollutants emerged [36]. Contrasting findings between infertility and $\mathrm{PM}_{2.5-10}$ were reported $[8,9]$.

Only three retrospective studies evaluated the effects of air pollution on IVF $[28,31,32]$. Although Legro and colleagues studied a large IVF population, the heterogeneity of IVF protocols and the lack of information about male partners represent two important limitation factors [28]. Moreover, the two studies conducted by Perin et al., are limited by the fact that only one pollutant was investigated and by the low number of cases enrolled [31,32].

Eight studies have been conducted on the general population. Of the three prospective studies, the one by Mahalingaiah et al. is the largest (more than 36,000 patients) and has the highest qualitative NOS score [8]. The quality of evidence was lowest in the study by Mohorovic et al. as was the number of observations, and the authors did not report effect size for each air pollutant separately [36]. The same weakness emerges in the Green et al. paper, which however analyzed such important factors as work exposure, residential history and employment status of the population studied [35]. Of the five retrospective studies conducted to-date, the quality of evidence is highest in two large studies conducted by Faiz and colleagues
[30] and by Slama and colleagues [29] demonstrating that air pollutants significantly affect fertility and stillbirths rates. The remaining three retrospective studies have several limitations, namely a paucity of data regarding the population studied [9], a low number of pollutant analyzed [33] and the methods adopted to assess exposure [34].

The relationship between air pollutants and spontaneous fertility was first observed in an animal model [37]. In detail, Mohallem et al. observed an increased implantation failure rate and a significant reduction of births in mice exposed to polluted city air compared to non-exposed mice [38]. Similarly, Veras et al. found significantly fewer antral follicles and a lower fertility index in mice exposed to traffic pollutants versus non-exposed mice [39].

The effect of air pollutants on human spermatogenesis has also been investigated [40-43]. The largest study, conducted by Hammoud et al., reported that $\mathrm{PM}_{2.5}$ exposure negatively correlated with sperm morphology and motility [40]. The negative effect of particulate matter was confirmed in a recent prospective cohort study that identified a significant association between $\mathrm{PM}_{10}$ and $\mathrm{PM}_{2.5}$ and sperm chromosomal abnormalities (i.e. disomy Y and disomy chromosome 21) [44].

The mechanism underlying the effect of air pollutants on female fertility is still a matter of debate. Several pathogenetic mechanisms have been proposed. Firstly, it was hypothesized that air pollutants could mimic the effect of androgens and estrogens in humans [45]. These endocrine-disrupting properties could exert their effect by interacting with nuclear receptor, the estrogen or androgen repertory or by interacting with specific targets in cytosol thus resulting in activation of the /Ras/Erk pathway [46]. Others have suggested that air pollutants could promote oxidative stress and inflammatory processes [17]. In this sense, we recently demonstrated that the addition of anti-oxidant factors to ovarian stimulation could improve reproductive outcome in women with polycystic ovarian syndrome [47]. However, whether antioxidant products could mitigate the effect of air pollutants on IVF outcomes remains to be determined. Finally, it has been suggested that air pollutants could exert a genotoxic effect. For instance, increased sperm DNA fragmentation was associated with exposure to elevated air pollution levels (at or above the upper limit of US air quality standards) [48]. Furthermore, DNA methylation seems to be significantly influenced by air pollutants [49]. Indeed, in a recent study of 777 men, an increase in air pollutant concentrations was significantly associated with F3, ICAM-1, and TLR-2 hypomethylation, and IFN- $\gamma$ and IL-6 hypermethylation [50].

Our review has several limitations. First, most of the studies included in our analysis are observational and retrospective, and hence more prone to bias. Second, exposure ascertainment was heterogeneous among studies. 
Most of the trials assessed air quality using a specific air monitoring station, others estimated exposure according to proximity to the potential source $[8,35,36]$. In addition, the reference levels of each pollutant varied significantly among studies. Lastly, the populations investigated as well as the definitions used to assess infertility and miscarriage were also heterogeneous. These factors render a meta-analytic and quantitative approach to this issue challenging.

In conclusion, our meta-analysis suggests there is a close association between female infertility and air pollution. However, a more robust meta-analytic approach is required before any definitive conclusion can be reached.

\section{Additional file}

Additional file 1: Table S1. Selection criteria according to PICO questions. (DOCX $14 \mathrm{~kb}$ )

\section{Abbreviations}

AOR: Adjusted Odds ratio; BMI: Body mass index; CO: Carbon monoxide; Cu: Copper; ERK: Extracellular Signal-regulated Kinase; F3: Tissue factor; FDR: Fecundability density ratio; HR: Hazard ratio; ICAM-1: Intercellular adhesion molecule 1; IL-6: Interleukin-6; INF- : Interferon gamma; IRR: incidence risk ratio; $\mathrm{NO}_{2}$ : Nitrogen dioxide; $\mathrm{NMHC}$ : Non-Methane hydrocarbons; NMOC: Non-Methane organic compounds; NOS: NewcastleOttawa Scale; $\mathrm{O}_{3}$ : Ozone; OR: Odds ratio; Pb: Lead; $\mathrm{PM}_{10}$ : Particulate matter of $10 \mu \mathrm{m} ; \mathrm{PM}_{2.5}$ : Particulate matter of $2.5 \mu \mathrm{m} ; \mathrm{PM}_{2.5-10}$ : Particulate matter of 2.5$10 \mu \mathrm{m}$ (coarse fraction).; RAS: Signal transducing protein; $\mathrm{SO}_{2}$ : Sulphur dioxide; SRC: Signal transducing protein tyrosine kinase; THC: Total hydrocarbons; TLR-2: Toll-like receptor 2

\section{Acknowledgements}

The authors would like to thank IVF Unit Federico II Staff.

The authors thank Jean Ann Gilder (Scientific Communication srl., Naples, Italy) for editing the text.

\section{Funding}

None.

\section{Availability of data and materials}

The datasets used and/or analyzed during the current study are available from the corresponding author on reasonable request.

\section{Authors' contributions}

CA, RP, GP and AC conceived the study. AC drafted the first version. MM, GC, CD, GC and PD contributed to data search and quality assessment. All authors read and approved the final manuscript.

\section{Ethics approval and consent to participate}

Not applicable (review of published papers).

\section{Consent for publication}

Not applicable (review of published papers).

\section{Competing interests}

The authors declare that they have no competing interests.

\section{Publisher's Note}

Springer Nature remains neutral with regard to jurisdictional claims in published maps and institutional affiliations.

\section{Author details}

${ }^{1}$ Dipartimento di Neuroscienze, Scienze Riproduttive ed Odontostomatologiche, Sezione di Ginecologia ed Ostetricia, Centro di
Sterilità Università "Federico II" di Napoli, Naples, Italy. ${ }^{2}$ I.O.S. \& COLEMAN Srl, Naples, Italy. ${ }^{3}$ Dipartimento di Medicina Clinica e Chirurgia, Sezione di Endocrinologia, Centro di Andrologia, Medicina della Riproduzione e della Sessualità Maschile e Femminile, Università "Federico II" di Napoli, Naples, Italy. ${ }^{4}$ Centro nazionale delle ricerche, Istituto per l'Endocrinologia e I'Oncologia Sperimentale (IEOS), Naples, Italy.

Received: 17 November 2017 Accepted: 24 October 2018

Published online: 30 December 2018

\section{References}

1. Talmor A, Dunphy B. Female obesity and infertility. Best Pract Res Clin Obstet Gynaecol. 2015;29:498-506.

2. Healy DL, Trounson AO, Andersen AN. Female infertility: causes and treatment. Lancet (London). 1994;343:1539-44.

3. ASRM. Effectiveness and treatment for unexplained infertility. Fertil Steril. 2006:86:S111-4

4. National Collaborating Centre for Ws, Children's H. National Institute for Health and Clinical Excellence: Guidance. Fertility: Assessment and Treatment for People with Fertility Problems. London: Royal College of Obstetricians \& Gynaecologists National Collaborating Centre for Women's and Children's Health; 2013.

5. Rocca ML, Venturella R, Mocciaro R, Di Cello A, Sacchinelli A, Russo V, et al. Polycystic ovary syndrome: chemical pharmacotherapy. Expert Opin Pharmacother. 2015;16:1369-93.

6. Alviggi C, Carrieri PB, Pivonello R, Scarano V, Pezzella M, De Placido G, et al. Association of pelvic endometriosis with alopecia universalis, autoimmune thyroiditis and multiple sclerosis. J Endocrinol Investig. 2006;29:182-9.

7. D'Argenio V, Nunziato M, D'Uonno N, Borrillo F, Vallone R, Conforti A, et al. Indications and limitations for preimplantation genetic diagnosis. Biochimica Clinica. 2017:41:314-21.

8. Mahalingaiah S, Hart JE, Laden F, Farland LV, Hewlett MM, Chavarro J, et al. Adult air pollution exposure and risk of infertility in the Nurses' Health Study II. Human Reprod. 2016;31:638-47.

9. Nieuwenhuijsen MJ, Basagana X, Dadvand P, Martinez D, Cirach M, Beelen R, et al. Air pollution and human fertility rates. Environ Int. 2014;70:9-14.

10. Alviggi C, Guadagni R, Conforti A, Coppola G, Picarelli S, De Rosa P, et al. Association between intrafollicular concentration of benzene and outcome of controlled ovarian stimulation in IVF/ICSI cycles: a pilot study. J Ovarian Res. 2014;7:67

11. Loomis D, Grosse Y, Lauby-Secretan B, El Ghissassi F, Bouvard V, BenbrahimTallaa $L$, et al. The carcinogenicity of outdoor air pollution. Lancet Oncol. 2013;14:1262-3.

12. Shah AS, Langrish JP, Nair H, McAllister DA, Hunter AL, Donaldson K, et al. Global association of air pollution and heart failure: a systematic review and meta-analysis. Lancet. 2013;382:1039-48.

13. Tomaskova H, Tomasek I, Slachtova H, Polaufova P, Splichalova A, Michalik J, et al. PM10 air pollution and acute hospital admissions for cardiovascular and respiratory causes in Ostrava. Cent Eur J Public Health. 2016;24(Suppl):S33-s9.

14. Li S, Williams G, Jalaludin B, Baker P. Panel studies of air pollution on children's lung function and respiratory symptoms: a literature review. J Asthma. 2012;49:895-910.

15. Dadvand P, Parker J, Bell ML, Bonzini M, Brauer M, Darrow LA, et al. Maternal exposure to particulate air pollution and term birth weight: a multi-country evaluation of effect and heterogeneity. Environ Health Perspect. 2013;121: 267-373.

16. Brauer M, Lencar C, Tamburic L, Koehoorn M, Demers P, Karr C. A cohort study of traffic-related air pollution impacts on birth outcomes. Environ Health Perspect. 2008;116:680-6.

17. Kampa M, Castanas E. Human health effects of air pollution. Environ Pollut. 2008;151:362-7.

18. Thron RW. Direct and indirect exposure to air pollution. Otolaryngol Head Neck Surg. 1996;114:281-5.

19. Ho SM, Johnson A, Tarapore P, Janakiram V, Zhang X, Leung YK. Environmental epigenetics and its implication on disease risk and health outcomes. ILAR J. 2012;53:289-305.

20. Santos-Silva AP, Andrade MN, Pereira-Rodrigues P, Paiva-Melo FD, Soares $P$, Graceli $J B$, et al. Frontiers in endocrine disruption: impacts of organotin on the hypothalamus-pituitary-thyroid axis. Mol Cell Endocrinol. 2018; 460:246-257. 
21. Alviggi C, Conforti A, Rosa PD, Strina I, Palomba S, Vallone R, et al. The distribution of stroma and antral follicles differs between insulin-resistance and hyperandrogenism related polycystic ovarian syndrome. Front Endocrinol. 2017:8:117.

22. Soave I, Caserta D, Wenger JM, Dessole S, Perino A, Marci R. Environment and endometriosis: a toxic relationship. Eur Rev Med Pharmacol Sci. 2015;19: 1964-72.

23. Lelieveld J, Evans JS, Fnais M, Giannadaki D, Pozzer A. The contribution of outdoor air pollution sources to premature mortality on a global scale. Nature. 2015;525:367-71.

24. Giannadaki D, Lelieveld J, Pozzer A. Implementing the US air quality standard for PM2.5 worldwide can prevent millions of premature deaths per year. Environ Health. 2016;15:88.

25. Moher D, Altman DG, Liberati A, Tetzlaff J. PRISMA statement. Epidemiology (Cambridge, Mass). 2011;22:128; author reply.

26. Adams J, Hillier-Brown FC, Moore HJ, Lake AA, Araujo-Soares V, White M, et al. Searching and synthesising 'grey literature' and 'grey information' in public health: critical reflections on three case studies. Syst Rev. 2016;5:164.

27. Wells G, Shea B, O'connell D, Peterson J, Welch V, Losos M, et al. Quality Assessment Scales for Observational Studies. Wiley: Ottawa Health Research Institute; 2004

28. Legro RS, Sauer MV, Mottla GL, Richter KS, Li X, Dodson WC, et al. Effect of air quality on assisted human reproduction. Hum Reprod. 2010;25:1317-24.

29. Slama R, Bottagisi S, Solansky I, Lepeule J, Giorgis-Allemand L, Sram R. Shortterm impact of atmospheric pollution on fecundability. Epidemiology. 2013; 24:871-9.

30. Faiz AS, Rhoads GG, Demissie K, Kruse L, Lin Y, Rich DQ. Ambient air pollution and the risk of stillbirth. Am J Epidemiol. 2012;176:308-16.

31. Perin PM, Maluf M, Czeresnia CE, Januario DA, Saldiva PH. Impact of shortterm preconceptional exposure to particulate air pollution on treatment outcome in couples undergoing in vitro fertilization and embryo transfer (IVF/ET). J Assist Reprod Genet. 2010;27:371-82.

32. Perin PM, Maluf M, Czeresnia CE, Nicolosi Foltran Januario DA, Nascimento Saldiva PH. Effects of exposure to high levels of particulate air pollution during the follicular phase of the conception cycle on pregnancy outcome in couples undergoing in vitro fertilization and embryo transfer. Fertil Steril. 2010;93:301-3.

33. Dejmek J, Jelinek R, Solansky I, Benes I, Sram RJ. Fecundability and parental exposure to ambient sulfur dioxide. Environ Health Perspect. 2000;108:647-54.

34. Sallmen M, Neto M, Mayan ON. Reduced fertility among shoe manufacturing workers. Occup Environ Med. 2008;65:518-24.

35. Green RS, Malig B, Windham GC, Fenster L, Ostro B, Swan S. Residential exposure to traffic and spontaneous abortion. Environ Health Perspect. 2009:117:1939-44.

36. Mohorovic L, Materljan E, Brumini G. Consequences of methemoglobinemia in pregnancy in newborns, children, and adults: issues raised by new findings on methemoglobin catabolism. J Matern Neonatal Med. 2010;23:956-9.

37. Carre J, Gatimel N, Moreau J, Parinaud J. Does air pollution play a role in infertility?: a systematic review. Environ Health. 2017:16:82.

38. Mohallem SV, de Araujo Lobo DJ, Pesquero CR, Assuncao JV, de Andre PA Saldiva $\mathrm{PH}$, et al. Decreased fertility in mice exposed to environmental air pollution in the city of Sao Paulo. Environ Res. 2005;98:196-202.

39. Veras MM, Damaceno-Rodrigues NR, Guimaraes Silva RM, Scoriza JN, Saldiva $\mathrm{PH}$, Caldini EG, et al. Chronic exposure to fine particulate matter emitted by traffic affects reproductive and fetal outcomes in mice. Environ Res. 2009; 109:536-43.

40. Hammoud A, Carrell DT, Gibson M, Sanderson M, Parker-Jones K, Peterson CM. Decreased sperm motility is associated with air pollution in Salt Lake City. Fertil Steril. 2010;93:1875-9.

41. Guven A, Kayikci A, Cam K, Arbak P, Balbay O, Cam M. Alterations in semen parameters of toll collectors working at motorways: does diesel exposure induce detrimental effects on semen? Andrologia. 2008;40:346-51.

42. Jurewicz J, Hanke W, Radwan M, Bonde JP. Environmental factors and semen quality. Int J Occup Med Environ Health. 2009;22:305-29.

43. de Angelis C, Galdiero M, Pivonello C, Salzano C, Gianfrilli D, Piscitelli P, et al. The environment and male reproduction: The effect of cadmium exposure on reproductive function and its implication in fertility. Reprod Toxicol. 2017;73:105-27.

44. Jurewicz J, Radwan M, Sobala W, Polanska K, Radwan P, Jakubowski L, et al. The relationship between exposure to air pollution and sperm disomy. Environ Mol Mutagen. 2015;56:50-9.
45. Okamura K, Kizu R, Toriba A, Murahashi T, Mizokami A, Burnstein KL, et al. Antiandrogenic activity of extracts of diesel exhaust particles emitted from diesel-engine truck under different engine loads and speeds. Toxicology. 2004:195:243-54.

46. De Coster S, Van Larebeke N. Endocrine-disrupting chemicals: associated disorders and mechanisms of action. J Environ Public Health. 2012;2012:713696.

47. Alviggi C, Cariati F, Conforti A, De Rosa P, Vallone R, Strina I, et al. The effect of FT500 Plus $\left.{ }^{\circledR}\right)$ on ovarian stimulation in PCOS women. Reprod Toxicol. 2016:59:40-4

48. Rubes J, Selevan SG, Evenson DP, Zudova D, Vozdova M, Zudova Z, et al. Episodic air pollution is associated with increased DNA fragmentation in human sperm without other changes in semen quality. Hum Reprod. 2005; 20:2776-83

49. Madrigano J, Baccarelli A, Mittleman MA, Wright RO, Sparrow D, Vokonas PS, et al. Prolonged exposure to particulate pollution, genes associated with glutathione pathways, and DNA methylation in a cohort of older men. Environ Health Perspect. 2011;119:977-82.

50. Bind MA, Lepeule J, Zanobetti A, Gasparrini A, Baccarelli A, Coull BA, et al. Air pollution and gene-specific methylation in the normative aging study: association, effect modification, and mediation analysis. Epigenetics. 2014;9:448-58.
Ready to submit your research? Choose BMC and benefit from:

- fast, convenient online submission

- thorough peer review by experienced researchers in your field

- rapid publication on acceptance

- support for research data, including large and complex data types

- gold Open Access which fosters wider collaboration and increased citations

- maximum visibility for your research: over $100 \mathrm{M}$ website views per year

At $\mathrm{BMC}$, research is always in progress.

Learn more biomedcentral.com/submissions 